\title{
MESSIANISMO E EXPROPRIAÇÃO CAMPONESA. UMA NOVA EXPEDIÇÃO AO REINO DA PEDRA ENCANTADA DO RODEADOR: PERNAMBUCO, 1820
}

\author{
Guillermo Palacios \\ El Colegio de México
}

\begin{abstract}
Resumo
O texto é um reestudo do 'acontecimento' conhecido na historiografia do século XIX como O Reino da Pedra Encantada do Rodeador, bem como uma análise da historiografia que construiu o 'acontecimento' e que se construiu ela mesma em torno da sua interpretação. Procurase estudar o episódio no contexto da desarticulação das sociedades de agricultores livres e pobres do Nordeste Oriental de finais do século XVIII e inícios do XIX e analisar, num caso específico, os modos de elaboração da historiografia que legitima a constituição do Estado nacional brasileiro do oitocentos.
\end{abstract}

\section{Abstract}

This article reestudies the 'incident' known in XIX-Century Brazilian literature as the Reino da Pedra Encantada do Rodeador, as well as the historiography that construed the 'incident' and, at the same time, built itself around its interpretation. It seeks to study the episode in the framework of the disintegration of the free and poor growers' societies of the Oriental Northeast at the end of the XVIIIth century and beginning of the XIXth, and to analyze the ways pursued by the elaboration of the historiography which would help to legitimate the building of the nineteenth-century national Brazilian State.

\section{Pallavras-Chave}

Camponeses $\bullet$ Messianismo $\bullet$ Historiografia $\bullet$ Milícias $\bullet$ Pernambuco

\section{Keywords}

Peasants $\bullet$ Messianism $\bullet$ Historiography $\bullet$ Militiae $・$ Pernambuco 


\section{Introdução}

Em meados de outubro de 1820, o Governador da Capitania de Pernambuco, Luís do Rego Barreto, nomeado três anos antes com a incumbência específica de reprimir a sangue e fogo a insurreição republicana de 1817, foi informado de que no alto da Serra do Rodeador, comarca do Bonito, no agreste setentrional de Pernambuco, formava-se um grande agrupamento de desertores e delinquentes, que, professando crenças sebastianistas, pretendia pegar em armas para derrubar o governo da Capitania ${ }^{1}$. Nos últimos dias do mesmo mês uma tropa de milicianos, comandada por um oficial bêbado, atacou a comunidade do Rodeador na madrugada em que centenas de indivíduos, predominantemente mulheres e crianças, aguardavam o anunciado desencantamento d'El-Rei D. Sebastião. O massacre que se seguiu foi coroado com o incêndio proposital das choupanas onde tinham-se refugiado os sobreviventes, muitos deles feridos. Os que tentaram escapar do fogo, sem distinção de sexo ou idade, foram passados a espada. Os que permaneceram dentro dos mocambos, foram queimados vivos. O Conselho de Investigação instaurado pelo próprio Governador após o incidente concluiu que os rebeldes tinham recebido o merecido castigo, e El-Rey, como de hábito, mandou impor perpétuo silêncio sobre o assunto.

Mas, em total desafio à autoridade real, o episódio, como foi classificado contemporaneamente, tem chamado a atenção de cronistas, historiadores, antropólogos, sociólogos e outros praticantes das ciências humanas de uma forma absolutamente incomum. $\mathrm{O}$ grosso da produção se concentra nas três décadas transcorridas entre 1860, ano que marca o início da revirada liberal após mais de vinte anos de domínio conservador, e 1890, o momento do triunfo das tendências reformistas que levaram, um ano antes, à queda do Império. Como não poderia deixar de ser, a sequiência de versões está evidentemente influenciada pelo acirrado clima de disputas ideológicodoutrinárias da época. A série se inicia com um documento anônimo de apenas quatro

\footnotetext{
${ }^{1}$ Sobre o Marechal Rego Barreto, Cf. Costa, 1962, v.VIII: 481-496. As instruções recebidas no ato da sua nomeação lhe mandavam "reduzir aquela capitania à sua devida sujeição".
} 
fólios, intitulado Narrativa referente a um ataque contra Bonito, publicado no Recife em 1860. Aproximadamente por essas mesmas datas, o general José Inácio de Abreu e Lima escreveu seu Combate do Rodeador ou da Pedra (1820). Vinte anos mais tarde, J. Augusto da Costa deu a conhecer Expedição do Rodeador. Pouco depois, em 1884, F.P. do Amaral editou diversas contribuições ao assunto no seu livro Escavações, fatos da história de Pernambuco, incluindo A Santa da Pedra, da sua autoria, e O Horroroso Massacre do Bonito, de Manoel Caetano de Almeida e Albuquerque. Por último, em 1890, outro militar, o coronel Francisco Benício das Chagas, acrescentou mais uma versão, intitulada História dos acontecimentos da Pedra do Rodeador. Nos anos posteriores a Canudos, naturalmente, a Pedra do Rodeador sofreu um poderoso eclipse, motivado pelo trágico esplendor da história de Antonio Conselheiro e os seus seguidores. Outros autores interessaram-se pelo assunto, mas em obras de caráter geral, como o próprio Varnhagen, que discutiu a questão no volume V da sua História Geral do Brasil, de 1854.

Ao longo do século XX, o episódio continuou interessando a historiadores e cientistas sociais. Assim, o cronista pernambucano J.A. Pereira da Costa, dedicou-lhe um apartado no capítulo "Superstições Populares” do seu Folk-Lore Pernambucano, publicado originalmente na Revista do Instituto Histórico e Geográfico Brasileiro em 1907, e voltou à Pedra no volume VIII dos seus Anais Pernambucanos (1951). Mais recentemente, no início da década de 1960, René Ribeiro dedicou-lhe um curto artigo, marcado pela minúcia da descrição antropológica, subtitulado "Um movimento milenar e sebastianista", e, pouco depois, Maria Isaura Pereira de Queiroz incluiu uma breve referência à Pedra do Rodeador no seu célebre Messianismo no Brasil e no Mundo(1965). É sintomático que sejam precisamente reflexões sobre movimentos messiânicos os últimos a fazerem referências mais ou menos extensivas ao movimento do Reino Encantado da Pedra do Rodeador, pois é essa a versão que se cristalizou na historiografia, sociologia e antropologia nacionais. Ou, como escreve F. P. do Amaral com deliciosa candura:

"Varias foram as versões que correrão acerca do ajuntamento que existió em principio do anno de 1820, na Serra do Rodeador, no Bonito. Uns consideravam em vista do exaltamento em que se achavam os animos em Pernambuco contra 
Luiz do Rego Barreto, seu Governador, como um ponto futuro de resistência aos actos da tyrannia e despotismo que elle diariamente praticava; outros affirmavam que era uma reunião de vagabundos e desertores que alli domiciliados, segregados do resto da sociedade, evitavam ser conhecidos e perseguidos, e que tiravam a sua manutenção da uberdade do solo que lavravam; outros, finalmente, diziam que eram uns phanaticos dirigidos por um especulador foragido das Lages do Canhôto, homem astuto, e velhaco, que havia feito das profecias do Bandarra, o seu principal meio de vida, o seu Potossi [...]. Esta versão foi a que se tornou mais corrente, e veio a ser a verdadeira, com pequenas alterações" (Amaral, 1884a: 156).

E, de fato, os aspectos messiânicos e milenaristas da Pedra do Rodeador são evidentemente os mais excitantes, seja para as perspectivas das modernas ciências sociais, seja para as visões proto-antropológicas e folcloristas da cientificista segunda metade do século XIX, pois eles mostram um comportamento alheio e deviant da norma estabelecida. Não é por acaso que nessas últimas décadas do século retrasado o resgate da chamada cultura popular se institucionalizou nos ambientes acadêmicos e nos círculos de estudiosos - como os Institutos e Academias de História e Geografia, etc. - e as suas manifestações, quanto mais exóticas melhor, foram cuidadosamente registradas. O Rodeador entra evidentemente nessa categoria de bizarra manifestação popular ${ }^{2}$.

Mas, embora sem o appeal que o sincretismo religioso parece ter, outros elementos podem ser igualmente destacados neste início do século XXI, à luz das novas perspectivas abertas pela historiografia, especialmente pela história agrária e, em grau semelhante, a história cultural. Esses elementos, que serão enfatizados neste texto, e que perseguem os fundamentos da segunda versão proposta por Amaral, são as características que parecem fazer do Rodeador um dos resultados da desa-

\footnotetext{
${ }^{2}$ Sobre a emergência da cultura popular como objeto de interesse científico existe uma ampla bibliografia recente. Cf. por exemplo, os clásicos Peter Burke, Cultura Popular na Idade Moderna. São Paulo, Companhia das Letras, 1989. pp.31-50; Geneviève Bollème, O Povo por Escrito. São Paulo, Martins Fontes, 1988. pp.11-50; Jacques Revel. "Formas de especialização: os intelectuais e a cultura "popular" em França (1650-1800)", em Revel, A Invenção da Sociedade. Lisboa, Difel, s/d.
} 
gregação da sociedade camponesa nordestina nas décadas precedentes. Alguns deles já foram destacados por outros autores, como Ribeiro, mas de maneira descontínua, no limite do anedótico, e não como elementos orgânicos de um processo maior. Não se trata de negar a dimensão messiânica do movimento, nem, muito menos, desprezar as questões de religiosidade popular - até porque é graças a elas que o registro do que aconteceu foi mantido e repetido ao longo de várias gerações de estudiosos. Também não se pretende revisar as narrativas precedentes no sentido do ordenamento dos fatos ou da concatenação dos acontecimentos; ambos esses aspectos estão suficientemente fixados e este trabalho não se propõe dizer coisas novas sobre $o$ que aconteceu. Trata apenas de ensaiar uma ampliação do foco de análise, de testar uma tese, no intuito de entender o Rodeador no marco do processo expropriatório do campesinato nordestino, e, simultaneamente, mapear melhor este processo mediante a análise de um momento privilegiado pela observação dos contemporâneos. Seria como esquecer por um momento do espírito e da carne, para prestar um pouco de atenção ao esqueleto. Não tanto o que aconteceu como porque aconteceu, e, especialmente, sob quem aconteceu.

\section{0 contexto}

De fato, as principais questões do processo de expropriação dos cultivadores pobres do Nordeste Oriental, conforme formuladas em trabalhos anteriores, estão presentes no Rodeador, um acontecimento que ocorreu, grosso modo, trinta anos depois de iniciada a expulsão das comunidades de cultivadores pobres e livres do litoral ${ }^{3}$. Os quatrocentos ou quinhentos devotos massacrados ou aprisionados na madrugada da sexta-feira, 26 de outubro de 1820, no alto da Pedra, eram uma minúscula fração de uma extensa camada de camponeses pobres que se afastavam das áreas

\footnotetext{
${ }^{3}$ Sobre o processo expropriatório dos cultivadores pobres livres de Pernambuco, cf. Palacios, 1998 (a ser traduzido próximamente pela Editora da Universidade de Brasília); para uma visão sintética veja-se Palacios, 1987.
} 
sob controle direto do Estado e se reunificavam com outros segmentos de cultivadores livres nos confins da zona escravista açucareira, perseguidos pelas campanhas promovidas contra eles pelo Estado colonial e pela crescente expansão das plantatations escravistas nas últimas décadas do século XVIII e primeiros anos do XIX. Que a comunidade do Rodeador tenha enveredado pelos caminhos do milenarismo proporciona uma roupagem miraculosa e radiante ao problema da expropriação, mas não o substitui, nem muito menos o resolve nem o oculta.

A região do Bonito, como grande parte das fronteiras de expansão da agricultura comercial do Nordeste Oriental nas primeiras décadas do século XIX, era um santuário de populações expulsas. Situada ao pé da serra do Macaco, generosamente irrigada pelas cabeceiras do rio Serinhaém e diversos afluentes do Unna, a região parecia no início do século recém aberta à expansão da agricultura. Bonito mantevese na mínima categoria de povoação até 1838 , evidenciando assim uma certa falta de importância econômica, ressaltada pela ausência de qualquer menção a culturas importantes de algodão durante os anos cobertos pelo conflito em pauta ${ }^{4} \mathrm{O}$ início de outra violenta campanha de recrutamento para os corpos de milícias no segundo semestre de 1818, cuja virulência e rigor não tinham precedente por causa do virtual estado de guerra existente na região, deve ter aumentado consideravelmente o fluxo migratório em direção ao interior (Barreto 1920: 11) ${ }^{5}$.

\footnotetext{
${ }^{4}$ Nos dias imediatos ao conflito, o Ouvidor do Recife descrevia assim a região do Bonito: "Estes terrenos, ha poucos annos, habitação de feras, existem hoje cultivados, e habitados, porque a sua producção e bondade tem atrahido gentes até de lugares remotos." Ouvidor Geral da Comarca do Recife a Governador da Capitania. Recife, 04.12.1820. IJJ'245. Cf. Gama, 1844. t. I: 56; Honorato, 1976: 23-24. Neste último texto já se menciona o cultivo de algodão como uma das principais atividades da área. Um artigo publicado em 1890 data a fundação da "primeira povoação do Bonito" apenas entre 1796 e 1798, acrescentando que "Em 1816 já havia uma grande povoação"("Municipio do Bonito",1890:74). Luis do Rêgo chama Bonito de "aldeia pobre, e cuja cultura consiste em algodão, que pertence a alguns lavradores deste genero, sendo o resto do povo mizeravel" (Barreto, 1820:15). O caráter de faixa de fronteira agricola de Bonito está estampado na sua pequena população de apenas mil e quinhentos escravos para mais de vinte e oito mil livres. Cf. Levantamento Estatistico da População de Pernambuco, 1822.
} 
Tudo indica que o fluxo de livres pobres em direção ao Rodeador se intensificou grandemente a partir do mês do início da campanha de repressão aos desertores. Para os fugitivos, a comunidade do Rodeador não tinha apenas a vantagem de estar situada numa serra de difícil acesso, mas nela encontravam uma perfeita identidade de propósitos, pois ai se reuniam pessoas que acreditavam "que as milícias e Tropas se acabarião logo que aparecesse El Rey Dom Sebastião" . Foi esse grande número de agricultores pobres evadidos do serviço militar e desertores dos corpos de milícias que se refugiavam no local, uma das pistas que levou ao descobrimento da comunidade de devotos, quando, em fins de setembro e começos de outubro de 1820, diversos corpos de tropa enviados a prender os transgressores foram atacados por membros do grupo ${ }^{7}$. A quebra do isolamento foi fatal: a partir desse momento, o ajuntamento da Pedra converteu-se em objeto de uma obsessiva e brutal campanha militar.

A própria origem do Rodeador, assim, está firmemente assentada na problemática da expropriação dos cultivadores pobres livres e dos seus mecanismos mais expressivos, entre eles o recrutamento militar. $\mathrm{O}$ fundador da comunidade, Silvestre Cesar dos Santos, o propheta, era ele mesmo um desertor que fugira do Canhoto, Termo das Alagoas, por volta de 1811-1812, no áuge das campanhas de recrutamento

\footnotetext{
${ }^{5}$ A campanha estava motivada também por boatos de uma "expedição que se preparava em Cadiz, e que se desconfiava poderia atacar pontos da costa do Brasil". A brutalidade da campanha foi um dos motivos, junto com o ataque ao Rodeador, que levaram Luis do Rêgo a se defender publicamente das críticas à sua administração.

${ }^{6}$ A declaração é do Capitão Manoel Bezerra de Mello, um dos oficiais comandantes da campanha no decorrer da qual tinha virado assíduo assistente aos rituais da Pedra. Depoimento prestado em 16.11.1820. "Processo Summario e Interrogatorio".

${ }^{7}$ Depoimento de João Maria da Silva, cabo de Milicias. 10.11.1820. “Autos de Devassa”. IJJ'245/ANRJ; "Vendo o commandante das milicias N. 12 do Bonito [sic] crescerem as deserções, resolveu mandar uma escolta prender os milicianos que haviam abandonado as suas bandeiras. Partiram para esse fim um alferes e 16 homens; porém, à primeira prisão que fizeram foi o preso tomado da força, e esta teve de retirar-se. Nova expedição com 23 homens, partiu no mesmo intuito para o Rodeador, sem melhor resultado. Chegando à noite nas proximidades da Serra, encontrou um dos desertores: prendeu-o, mas deixou livre a mulher do preso com um filhinho, mandando-a recolher-se a casa. No amanhecer, viu o tenente que todo o povo estava a espreita [...]. Reconhecendo a inutilidade de tentar novas prisões, retirouse para o Bonito e levou ao conhecimento do seu commandante [...]" (Costa, 1890: 348-349).
} 
ordenadas pelo governador Caetano Pinto de Miranda Montenegro, acompanhado ou prontamente seguido por quatro irmãos, cinco cunhados, e um número não especificado de mulheres, todos mulatos como ele. Chegados no Bonito, teriam rapidamente entrado em associação com vizinhos. Com ele, ou um pouco depois, teriam chegado outros que fugiam da mesma ameaça, e que teriam composto, com irmãos, cunhados e compadres do Silvestre, o núcleo original da agremiação ${ }^{8}$. Além de jovens fugindo do recrutamento, milicianos desertores das suas unidades tinham se dirigido igualmente "para aquelles sitios [onde] apoiados, congregados com o Silvestre Cesar e sua parentella [...] faziam hum corpo respeitavel de cincoenta homens". ${ }^{9}$ Aos poucos, a comunidade criou as condições necessárias para acolher outros desertores, convertendo-se assim num foco de atração de marginalizados, desclassificados e perseguidos. Os fugitivos do recrutamento e os milicianos desertores não chegaram sozinhos, mas acompanhados de suas famílias. Com elas se instalaram na serra e nas escarpas "por ser bom o terreno" ${ }^{10}$. Eram, pois, predominantemente, famílias de agricultores, embora entre os fugitivos do recrutamento abundassem os "moços solteiros", os mais visados pelas autoridades ".

\footnotetext{
${ }^{8}$ Depoimento de João Maria da Silva, Cabo das Milicias. 10.11.1820. 'Autos de Devassa'.JJJ9245/ANRJ.

${ }^{9}$ Depoimento de Jozé Joaquim Pereira. 11.11.1820. "Autos de Devassa”. IJJ'245/ANRJ

${ }^{10}$ Depoimento de Manoel Pereira dos Santos. 10.11.1820. "Autos de Devassa." IJJ $245 /$ ANRJ

${ }^{11}$ Depoimento de Antonio Bezerra de Mello, Aferes de Ordenanças. 17.11.1820. "Autos de Devassa". IJJ'245/ANRJ. O testemunha, falando da sua experiência de oficial, informou que os desertores fugiam do serviço da tropa de linha e das milicias, mas não dos corpos de ordenanças: "que para as diligencias, e trabalho das Ordenanças estavão sempre prontos". É dificil estabelecer o número de habitantes do Rodeador, pois tudo indica uma grande rotatividade provocada pelas rezas, cerimônias e graus de envolvimento com os ritos. Embora se fale em até quinhentos indivíduos presentes na hora do ataque do exército, o Cirurgião-Mor "observou pelo numero, e grandeza das habitações chamadas mocambos, que o numero de pessoas que ali habitavão fixamente montaria a cem, ou cento e vinte"; já um dos soldados do Batalhão de Milicias, declarou que "só havia quatro mocambos pequenos, em que podia habitar pouca gente". Depoimento do Cirurgião-Mor do $11^{\circ}$ Batalhão 07.11.1820; Depoimento de Caetano Jozé Ferreira de Moraes. mesma data. "Autos da Devassa". IJJ $^{9} 245 / A N R J$. Já Antonio Pereira informou "que pouco mais ou menos serião duzentos e tantos homens, e que de mulheres maior numero [...]". Depoimento de Antonio Pereira. 28.10.1820. "Conselho de Investigação". IJJ'245/ANRJ.
} 
O alarme partira do Comandante do Distrito, advertido pelo alferes da tropa atacada na serra, que informou o Governador sobre "a existência de hum grande numero de homens armados no sitio da Pedra do Rodeador, os quaes fugindo da obediencia das auctoridades, e acolhendo os desertores de diversas provincias, augmentavão consideravelmente em força". Para confirmar a versão, um espião, "official do paiz", infiltrou-se na comunidade da Pedra por ordens do Governador. O informe do pombeiro consolidou a versão oficial, e convenceu Luis do Rêgo de que "o ajuntamento era mui perigoso, e que tendia a formar grandes desordens na sociedade" ${ }^{12}$. O medo do governo da Capitania cresceu conforme comandantes militares da região reportavam o incremento do grupo do Rodeador, "que dentro de em pouco montarião a bastantes centenares", e testemunhavam "que o seu objecto era decididamente hostil; em fim que ali se estava propagando um scisma religioso e politico" (Barreto, 1820: 16). As notícias indicavam "que huns sessenta homens e muitas mulheres se havião entranhado na Serra do Rodeador, aonde vivião dados a supertições ridiculas, as quais derramavão alliciando assim muitos crédulos, cujo numero hia progredindo em virtude de huma notavel fascinação" ${ }^{13}$.

Como se percebe facilmente no teor dos textos da época, além da gravidade da crise militar, a desorganização social provocada tanto pelos movimentos políticos das elites nativistas quanto pelos efeitos da desagregação das comunidades campone-

\footnotetext{
${ }^{12}$ Cf. Governador de Pernambuco a Ministro do Reino. Recife, 30.10.1820, em IJJ ${ }^{9}$ 245/ANRJ. O "pombeiro" era o Tenente Ribeiro Freire, comandante da primeira força que tinha feito contato com a comunidade. Cf. Costa, 1890: 349.

${ }^{13}$ Governador de Pernambuco a Ministro do Reino. Recife, 30.10.1820, em IJJ ${ }^{9}$ 245/ANRJ. As informações de autoridades militares são atribuidas a um "Comandante do Batalhão da Serra", talvez o próprio Madureira. A justificativa de Luis do Rego para a sua desastrada atuação na repressão do Rodeador está recheada de evidências de desentendimentos entre ele e os Ouvidores de Olinda e de Recife, seus inimigos políticos que, ao contrário das versões que encontravam acolhida nos ouvidos do Governador, achavam tratar-se "o ajuntamento do Rodeador huma Povoação de gente pacifica e laboriosa [...] só para ennegrecer-me”. O Ouvidor de Olinda, em particular, segundo Rego, "chama a si gente do mato, e lhe faz graves sermões contra o meu systema de milicias que apellida de tumula da agricultura e prosperidade do paiz".
} 
sas do litoral, fomentava um clima de violência e criminalidade que, para o cambaleante governo da Capitania, rivalizava em periculosidade e - mais importante - se confundia no significado com as questões referentes à sobrevivência ou não do regime colonial. O extremo sul da Província, particularmente as áreas de densas florestas da região limítrofe com a comarca das Alagoas, tinha-se convertido num território controlado por grandes bandos armados de criminosos e foras-da-lei, muitos deles cultivadores pobres livres evadidos do serviço militar. Descobertos em março/abril de 1820, os bandos chefiados por José de Barros e o "club do Boique", compostos cada um por perto de quinhentos homens fortemente armados, foram desbaratados pouco depois ${ }^{14}$. Mas eles forneceram os antecedentes imediatos e o perfil para reforçar as características criminosas do ajuntamento do Rodeador. De fato, a semelhança na descrição textual do descobrimento e destruição das quadrilhas de assaltantes com o achado e destruição da comunidade do Rodeador é sintomática porque repetitiva e nulificadora de qualquer diferença, pois iguala situações que foram empiricamente incomparáveis, e produz como reflexo do imaginário dos representantes do Estado a visão de uma identidade formal irrefutável entre bandidos e pobres livres. A identificação de ambas as situações é absolutamente linear no discurso do poder do Estado: as quadrilhas de assassinos e assaltantes tinham acabado de ser destruídas, disse Luís do Rego, "e ainda as tropas se não tinhão recolhido á capital quando soube do ajuntamento do Rodeador"; assim, concluía o Governador, "no deixei de julgar provavel que fosse parte, ou destacamento do grande bando de salteadores, que eu mandei perseguir, e que se dizia communicar-se com diversos". Até o montante dos participantes era o mesmo: 400 (Barreto 1820: 16). As linhas entre a liberdade e o crime eram, de fato, extremamente tênues na sociedade escravista.

\footnotetext{
${ }^{14} \mathrm{O}$ alarme provocado levou o General Rego Barreto a solicitar que outras provincias enviassem tropas para um ataque combinado, mas no fim bastou "um forte troço de infantes com alguns cavallos [para] perseguir a grande quadrilha que foi destruida com a prisão de alguns fascinoras e com a morte do seu Chefe" (Barreto 1820:15).
} 


\section{Os fatos das versões}

Os fatos incorporados nas versões derivadas do episódio do Rodeador - falo das narrativas stricto sensu, e não dos estudos acadêmicos modernos, por mais que estes sejam passíveis do mesmo enquadramento - servem para diferenciar umas das outras na identificação que fazem da natureza da agremiação e, a partir daí, do seu grau de periculosidade para o status quo. Existe uma versão que privilegia o aspecto político do grupo e o seu desafio armado ao governo, e que se junta com a perspectiva criminosa do agrupamento. Outra que enfatiza a transgressão religiosa, e aponta para os perigos implícitos na manipulação de superstições e crendices realizada por indivíduos espertos para enganar matutos ingênuos. Nesta, as ameaças ao Estado - "o scisma político e religioso" - estão contidas nos ataques à legitimidade do poder oficial e na contralegitimidade que os supostos rebeldes elaboram através da lenda sebastianista, isto é, através dos protestos de lealdade ao rei velho e à verdadeira religião. Quando reunida nos contornos da versão anterior, ambas constroem uma variante que se torna real e verídica para a perspectiva de um poder que enfrenta um tempo de crise, um momento altamente favorável para a produção, dentre outras coisas, de imaginários sociais contraditórios (Baczko 1991: 29). Uma terceira desestrutura os aspectos conspirativos das duas anteriores, e parte para uma perspectiva que se pode chamar de naturalista, onde os habitantes do Rodeador se aproximam de simples camponeses assustados e famintos. Mas as versões não são gratuitas, nem inocentes, independentemente do grau de verdade que contenham. Elas têm a sua história.

Conviria estabelecer, entre outras coisas, o tempo das versões e como elas são produzidas. A versão sobre a conspiração de cunho político-militar é a primeira a surgir, incrementada, como já disse, pelas tintas da criminalidade tomadas emprestadas das quadrilhas de José de Barros e do Boique. Ela é arquitetada pelos espiões do governo, fortalecida por sucessivos informes de chefes militares da área e consolidada pelo encarregado de fazer o registro oficial do massacre, um oficial subordinado do comandante do ataque. No essencial, ela precede - e prescinde do ataque pois, em grande medida, o dirige e o adapta para os fins que ela mesma iden- 
tifica. Não é a versão que se fixa na história, como esclarece Amaral, mas é, sim e talvez por isso tenha caído em desgraça -, a versão apoiada pelo poder agonizante, aí incluido o Governo da Capitania, o Ministério do Império e a grande imprensa europeizada da capital do Brasil. Em certo sentido, é uma versão que não precisa dos fatos. Nela, o argumento religioso e místico entra como um fundamento de legitimidade e poder. A destruição do Rodeador castiga igualmente o desafio político-religioso, a manipulação ilegítima exercida pelos lideres do movimento e a ignorância culposa dos devotos. Estes últimos ingredientes, que descobrem a natureza ritual do agrupamento, a sua relação com o processo de desencantamento do Estado, são acrescentados a partir do depoimento dos prisioneiros, confusos, incompletos, derrotados.

Os inquéritos e devassas conduzidos pelas autoridades militares verticalmente ligadas ao Governador e ao Ministério, realizados após a destruição da comunidade do Rodeador, solidificam esta versão, enfatizando naturalmente os aspectos ameaçadores do grupo e mostrando o simplismo da roupagem sebastianista das reuniões, a ausência de qualquer base de legitimidade. Essa característica é o centro da versão naturalista, que coincidentemente pode ser identificada como uma versão civil, pois é elaborada no essencial pelos Ouvidores de Olinda e do Recife, que conduzem as suas próprias averiguações. Ambos são inimigos declarados e reconhecidos do Governador, e a contraposição das versões está enquandrada nesse contexto de rivalidade política local. Esta é uma versão inteiramente posterior ao movimento e à sua repressão, decorrente dos depoimentos dos sobreviventes, e parece ser produzida por agentes de uma situação que não encontra maiores ameaças nos acontecimentos da comarca do Bonito. Paternalista, desqualifica a periculosidade e ressalta a inocência dos devotos.

\section{As versões dos fatos}

\section{a. A construção da causa}

O primeiro registro que se conserva sob os preparativos de uma operação militar contra um grupo de civis reunidos no alto da Serra do Rodeador, data de 20 de outubro de 1820 e trata-se de uma correspondência enviada ao Governador e Capitão General pelo Major da $1^{\mathrm{a}}$ Linha e Comandante da $2^{\mathrm{a}}$ Brigada de milícias do Limoeiro, 
José de Morais Madureira Lobo. Nela se indica que tropas milicianas preparavamse para cercar os rebeldes da Serra do Rodeador, perversos que já chegavam a "mais de duzentos homens, armados de Bucamartes, facas e parnalibas e polvora bastante para se defenderem" ${ }^{\prime 15}$. A justificativa da necessidade da repressão está elaborada num segundo documento da mesma data, com base em notícias transmitidas pelo pombeiro, que reforçavam, consciente ou inconscientemente, o perigo da contralegitimação que se difundia pela comarca do Bonito a partir do núcleo do Rodeador. Como primeiro elemento, o agente constatou "não se fallar em outra coisa mais que em taes homens, e seus milagres estando aquelle Povo numa confuzão tal, que admira". Os taes homens asseguravam que seriam atacados pelo exército, mas que nada lhes aconteceria pois "que modo algum tem de serem offendidos porque elles só he que servem a Deos, e ao verdadeiro Rey que lhes aparesse dizendo ser El Rey D. Sebastião”. Inversamente, a coraça de proteção garantida pelo encantamento alvejava os inimigos, convertia-se na ameaça de "castigar os que se não querem alistar no seu partido". Um dos membros do grupo, Jozé Tabocas "o qual entrou na lista com toda sua familia", teria declarado em entrevista ao informante - "(chorando muito) [...] que a V.Exca he que elles lá querião para lhe fazerem a cabeça em duas cuias para velhas beberem agoa". Mais não disse, sobretudo sobre "as grandes couzas que vêm por lhe ser prohibido". Tabocas adiantou, no entanto, que no centro do lugar das reuniões existia uma pedra com um cruz cravada, da qual sairia El Rey D. Sebastião no dia do ataque do exército, e que nessa pedra escutavam-se "manejos d'armas, fogos d'espada, e instrumentos de musica tocando" ${ }^{\text {"16 }}$.

O informe do pombeiro concluía com alguns dados de interesse militar: era público que os devotos tinham "muito e bom armamento", que executavam algum tipo de exercício militar regular e, sobretudo, que estavam ansiosos por iniciar a refrega: "suspiravão a Tropa fosse breve por que do contrario elles sahio a campo a

\footnotetext{
${ }^{15} \mathrm{Cm}^{\text {te }}$ da 2a. Brigada de Milicias a Governador. Quartel Geral do Limoeiro, 20.10.1820. IJJ $245 /$ ANRJ.

${ }^{16} \mathrm{Cm}^{\text {te }}$ da $2^{\text {a }}$ Brigada a Governador. Limoeiro, 20.10.1820. JJJ $^{9} 245 /$ ANRJ.
} 
publicar o seu Rey". Também estavam relativamente bem aparelhados em questões de material de reposição: o agente tinha ouvido dizer que contavam com dois ferreiros que funcionavam como armeiros, um santo de ouro "que terá hum cavalo de altura", e, mais inquietante, que um oficial da tropa regular do exército, o Tenente Antonio Ribeiro Freire, "ia todos os dias ver o milagre",

\section{b. 0 ataque}

Uma vez identificadas as supostas quebras da legalidade praticadas pelos reunidos na Pedra do Rodeador e tipificados os ataques à legitimidade do poder oficial, começou o envio de tropas de milícias de diversos pontos da Província para estabelecer, segundo o Governador, um cerco preventivo à comunidade de rebeldes/devotos, enquanto a tropa de linha partia do Recife ${ }^{18}$. O cerco foi iniciado por um batalhão miliciano, "commandado por um tal Major Madureira, homem audaz e imprudente" (Narrativa c1860: 1). Mas, ao invés de esperar a chegada da tropa de linha, Madureira decidiu antecipar-se e atacar. $\mathrm{O}$ ataque consumou-se na madrugada da sexta feira 26 de outubro. Essa noite, quatro ou cinco centenas de pessoas tinham acudido ao local das cerimônias, alertados pelos líderes da comunidade da iminência do desencantamento d'El-Rei ${ }^{19}$. Mas o milagre provou ser um paradoxo trágico. O assalto foi minuciosamente registrado por um oficial subordinado, como se tivesse sido uma verdadeira batalha contra um poderoso inimigo que teria apresentado "a mais brava resistencia". Sem a menor censura, o oficial confirmou que após a ocupação do povoado dos devotos "se poz fogo aos Mocambos que queimou todos os feridos que

\footnotetext{
${ }^{17}$ loc. cit.

${ }^{18}$ A tropa expedicionária estava composta por dois Batalhões de Caçadores e parte do Esquadrão de Cavalaria de Linha, aos que se juntaram ainda três batalhões de milicias provenientes de freguesias vizinhas, Limoeiro, Bezerros e do próprio Bonito e uma meia brigada de cavalaria de milicias, todos sob o comando do Marechal Luiz Antonio Salazar e Moscoso, "homem prudente, cheio de experiencia, e de caracter brando, humano" (Barreto 1820: 17-18).

19 "[...] o ajuntamento na noite da diligencia montaria a mais de quantro centas pessoas a maior parte mulheres e crianças". Depoimento de Alejandre Magno dos Reis. 07.11.1820. "Autos de Devassa". IJJ $^{9}$ 245/ANRJ.
} 
estavão dentro chegando a mais de setenta incluzo algumas mulheres, e o resto foi prezioneiro e morto escapando-se alguns que se poderão occultar pelas grutas da dença Matta" ${ }^{20}$. A operação de assalto à Pedra tinha sido igualmente bárbara. Ordenada ainda na escuridão da madrugada, num terreno desconhecido, e realizada por homens mal treinados e sumamente nervosos, conduzidos por um oficial embriagado, deu por resultado uma enorme quantidade de mortos e feridos entre a tropa, por causa de fogo cruzado. Ao que tudo indica Madureira ordenou a escalada da Pedra por flancos opostos, de maneira a cercar os "rebeldes" no topo e, na escuridão da madrugada, foi impossível distinguir amigos de inimigos ${ }^{21}$. As tropas de linha enviadas no encalço da força de Madureira, obstaculizadas pelas chuvas e as enchentes dos rios, só conseguiram chegar no alto da Pedra na manhã seguinte aos acontecimentos, quando teriam se deparando com a seguinte cena:

“[...] o tal Major Madureira, em mangas de camisa e muito bébado, estava mandando dar por um sargento dusias e dusias de palmatoadas em algumas mulheres, e já tinham apanhado como umas cinco ou seis daquellas infelizas quando chegou o Marechal e fez cessar tão barbaro castigo" (Abreu e Lima 1860: 252).

Nos dias subseqüentes, a tropa de Salazar e Moscoso realizou uma "limpeza" exaustiva da Serra do Rodeador, destruindo todos os "mucambos" e choupanas en-

\footnotetext{
${ }^{20} \mathrm{~T}^{\mathrm{te}}$ Coronel Comandante a Governador. Bonito, 26.10.1820. IJJ'245/ANRJ. Abreu e Lima é o único cronista mencionar as barbaridades cometidas pela tropa após o ataque (Abreu e Lima 1860: 253). ${ }^{21}$ O general Abreu e Lima descreve assim os desastrados movimentos da tropa: "Estreitando o circulo, e aproximando-se indistinctamente os Corpos, o fogo foi-se cruzando em toda a periferia e o resultado é que mutuamente se fuzilaram, e houve uma mortandade horrorosa, tanto dos corpos de linha como de milicias [...] A proporção que a tropa subia pela encosta acima, foram ficando grupos mais ou menos avançados, o que deu lugar a terriveis enfanos: uma Companhia de milicias, que se aproximava pela retaguarda da avançada, rompeu fogo sobre esta, que fez meia volta e correspondeu ao ataque com toda a bisarria, fazendo recuar a tal Companhia, que deixou muitos mortos e feridos. Finalmente o dia veio mostrar o resultado desta operação tão estupidamente ordenada como executada". (Abreu e Lima c1860: 253); já o Tenente que registrou oficialmente o ataque, informou ter havido poucas baixas: dois mortos, 7 feridos de gravidade e 17 sem consequências. A Gazeta do Rio de Janeiro, na sua edição de 25.01.1821, reproduz a versão mais maniqueista do acontecimento, e indica que os "rebeldes" tiveram 79 mortos.
} 
contrados e prendendo quem tinha a desgraça de aparecer-lhe pela frente, sem a menor averiguação sobre seus graus de participação no conflito: "por isso o numero de Prezos he grande, e entre estes ha grande numero de feridos"

Porém, indiferente às evidências de excessos tanto na interpretação do sentido quanto na repressão ao grupo do Rodeador, o Governador, mandante final do ataque, preferiu apoiar a versão justificativa dos comandantes do front, e deixou para a posteridade a informação de que um erro de cálculo tinha feito a tropa se aproximar demais do reduto dos devotos, ser descoberta e atacada por estes. A hecatombe que se seguiu teria sido apenas um ato de legítima defesa da força armada, determinado por "huma desinteligencia frequente em taes circunstancias" (Barreto 1820: 18). No entanto, há suficientes indícios - alguns deles inseridos na própria narrativa do Governador - que apoiam a idéia de que os tiros efetivamente disparados pelos seguidores de Silvestre, quando as tropas se aproximavam do acampamento, não tinham nenhuma relação com essa ameaça: eram apenas parte do precário ritual constituído pela seita, e tinham por fim anunciar a alvorada. O rito incluía uma descarga cerrada de espingardas no amanhecer, mas "quando os matutos principiarão com suas descargas, foi que o Commde Madureira mandou romper o fogo" (loc. cit). Uma vez constatado o massacre de pessoas inocentes, crianças, mulheres e velhos indefesos, que estavam ai para rezar, apenas acompanhados por um punhado de homens armados e ensandecidos, Madureira procedeu a elaborar a versão oficial, que classificava o acontecido como um movimento de rebeldia contra o governo da Província, que teria oferecido encarniçada resistência ao exército, e que somente pôde ser submetido a sangue e fogo. Montada a interpretação, obrigou os prisioneiros, isto é, os sobreviventes, a

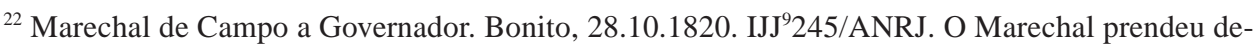
zenas de mulheres mas ficou sem saber o que fazer com elas "porque me lembro que na revolução de Pernambuco não foram prezas". Por outro lado, mostrou-se pessimista quanto a que o massacre dos devotos tivesse de fato significado o fim das causas do conflito, pois, dizia, "estou bem persuadido que nestes contornos a maior parte dos Habitantes são do mesmo modo de pençar". Silvestre e os outros líderes, a exceção de Manoel Gomes, tinham conseguido fugir. Idem a Idem. Bonito, 29.10.1829. IJJ'245/ANRJ.
} 
marcharem junto com a tropa até o Recife, acorrentados, encenando então uma infeliz "entrada triunfal" na capital da Província ${ }^{23}$.

\section{Os fatos e as versões}

Em princípios de novembro de 1820 foram instalados diversos processos de averiguação sobre os acontecimentos do Rodeador, que se alastraram por um mês inteiro e produziram documentos importantíssimos. Neles aparecem os interrogatórios de 23 indivíduos, homens e mulheres, acusados de serem membros do grupo do Rodeador, depoimentos de oficiais e soldados que tomaram parte do ataque, declarações de vizinhos e moradores das redondezas que conheciam a comunidade, arrolados como testemunhas, e outros, que constituem uma amostra excepcional, embora aleatória e limitada, para divagar sobre o contexto social do movimento, e levantar algumas hipóteses sobre as conseqüências da expropriação. Esses depoimentos contêm os únicos dados primários que restam para nos aproximarmos da visão dos vencidos neste episódio - por mais que essa velha classificação das fontes não tenha já mais outro sentido do que a palavra "versão" 24 .

\footnotetext{
${ }^{23}$ Essa manobra "produziu na Cid ${ }^{\mathrm{e}}$ geral indignação, e disgosto em todas as classes", o que levou o general governador da Capitania a proveer condições para descanso e cura dos feridos e, no seu tempo, liberta-los, embora previamente identificados em diligências policiais (Narrativa, c1860:.3). "VEx ${ }^{\text {ca }}$ verá que ha hum numero extraordinario de mulheres, e meninos; excepto os pertencentes aos Cabeças e aos que mais criminosos fossem, mando que os restantes e seus filhos escolhão domicilio; e que tomada a lista dos seus nomes sejão recommendados aos Comandantes Militares [...]. Os meninos sem pais ordeno que venham para esta; os machos de idade capaz [serão aprendizes nos quartéis]; e as femeas ou machos muito pequenos serão distribuidos por familias [...]". Governador de Pernambuco a Ministro do Reino. Recife, 30.10.1820. IJJ $^{9} 245 / A N R J$. O número dos "prisioneiros" foi estimado entre 80 e 100 individuos "de ambos os sexos [...]. Chegando ao Recife os desgraçados presos do Rodeador foram recolhidos á Cadeia no mais lastimoso estado de miseria [...]. Foi tal a indisciplina da tropa, que aqueles infelizes foram completamente saqueados: mas havendo disso queixa fez-se uma indagação, cujo resultado foi que a maior parte do roubo passou então para as máos de um dos chefes da expedição" (Abreu e Lima, c1860: 253).

24 "Conselho de Investigação para conhecer algumas circunstancias mais essenciaes dos Rebeldes da Pedra do Rodeador". Recife,, 28.10.1820; "Processo Summario e Interrogatorios feitos aos prezos que assistião na Serra do Rodeador, e em outros differentes lugares pertencentes a esta Provincia de Pernambuco". Recife, 06.11.1820; "Auto da Devassa a que mandou proceder o Dezembargador
} 


\section{a. A elaboração ex post da lenda}

A lenda do "Reino do Paraizo Terrenal", da "Santa da Pedra" onde estava encantado El-Rei D. Sebastião, da "Pedra do Encantado", com todos seus atributos, formas de organização, modelos de comportamento, fundamentos e objetivos, etc., conforme os conhecemos, foi elaborada depois da destruição da comunidade do Rodeador, ao longo dos depoimentos de participantes e testemunhas ${ }^{25}$. Os interrogatórios, fossem eles orientados em busca do perigo político-militar-ideológico contido no movimento, fossem então dirigidos para destacar a natureza pacífica e ingênua dos devotos e o abuso do poder militar português, construíram o corpo da lenda com graus de detalhe, harmonia, coerência e determinação que certamente não existiam integralmente no imaginário de nenhum dos membros do grupo, nem sequer - ou melhor, sobretudo - entre os dirigentes. Trata-se de uma construção ideológica ex post, que em grande medida serve para adequar aos acontecimentos que levaram à destruição da comunidade e para explicá-los, ordená-los na narrativa - e na memória - dos depoentes. Mas não os explica e ordena em determinada direção, pois a lenda surge desse conjunto de representações registrado pelos escrivães do governo de Pernambuco como uma construção imaculada, preservada dentro da sua própria liturgia, indiferente aos sentidos para os quais possa servir. A guerra das versões não a afeta, e ela emerge praticamente a mesma para todas as partes envolvidas.

A lenda, naturalmente, estava centrada no encantamento d'El-Rei D. Sebastião, $o$ Grande Encoberto, e da iminência de diversos milagres assim que o encantamento

Ouvidor Geral, e Corregedor Antero Jozé de Maia e Silva, pelos motivos abaixo declarados [...]”. Recife, 07.11.1820; "Processo Summario e Inquisição de Testemunhas sobre o Ajuntamento e Sociedade da Serra do Rodeador desta Provincia de Pernambuco. Auto de Corpo de Delicto". Recife, 11.11.1820; "Interrogatorios feitos as Mulheres, que forão encontradas no Rodiador, e que se achão prezas pelos acontecimentos ali praticados". Recife, 21.11.1820; "Auto de perguntas feitas a Manoel da Paixão, Pai, e ao seu filho do mesmo nome”. Recife, 22.11.1820. Todos em IJJ'245/ANRJ.

${ }^{25} \mathrm{O}$ que se segue é o essencial da lenda para os propósitos deste texto, que não são, como advertido na Introdução, os de reconstruir novamente o "episódio do Rodeador", por mais que não seja possível evitar outra versão. Os interessados nos detalhes do ritual sebastianista devem consultar a bibliografia citada, particularmente Ribeiro (1960). 
terminasse. Para aguardar e propiciar esse acontecimento, a comunidade reunida no alto da serra, perto da laje onde estaria a fonte do mistério, realizava rezas, confissões, penitências, etc., que recebiam nomes apropriados da natureza miraculosa do que acontecia: "santas insinuações", "santos louvores", etc. O esquema de organização misturava, como é próprio do sebastianismo, exercícios espirituais e para ou melhor pseudomilitares. O controle da comunidade estava nas mãos do núcleo do grupo fundador, composto por Silvestre dos Santos, o propheta, quatro irmãos e cinco cunhados. Naturalmente, o mando correspondia ao primeiro, cuja legitimidade original decorria de que tinha “ido ao Paraiso Terreal, e lá tinha visto El Rey Dom Sebastião, a Dom João de Deus, ao Principe Dom Antonio Imperador da Divina Magestade, a Dom Francisco e Dom Pedro”. Mas o arquiteto era o seu cunhado, Manoel Gomes, o ideólogo do grupo. Era este quem tinha construído o relato que fundamentava a lenda e quem, no dizer de alguns ex-participantes, tinha mudado a natureza da comunidade a partir da sua incorporação ao núcleo central ${ }^{26}$.

Assim, uma vez instalados na sua nova moradia na Serra do Rodeador, Silvestre e seus amigos teriam passado a promover reuniões de rezas nas suas casas. Ao longo dos vários anos transcorridos entre a chegada e organização do grupo e o alarme do Estado, a afluência de homens e mulheres simples dos arredores, camponeses como eles, alguns mascates e artesãos, "gente sem representação", ${ }^{27}$ deu outra dimensão ao que tinha sido no início uma assembléia familiar, e transformou a reza cristã num complicado ritual sebastianista. Simultaneamente, o culto transformou-se também num negócio. Manoel Gomes, “o tal Paixão”, aparecera na comunidade por volta de 1819. Com a sua chegada iniciou-se a normatização do que fôra até então uma

\footnotetext{
${ }^{26}$ Depoimento de João Fco da Silva. 09.11.1820. "Autos de Devassa”. Manoel Gomes, ou Manoel da Paixão, morto no combate final, era o único membro da comunidade plenamente alfabetizado. “Conselho de Investigação". Depoimento de Antonio Pereira. 28.10.1820. Ambos em IJJ'245/ANRJ. $\mathrm{O}$ fato dele ter sucumbido nos combates pode ser um agravante da importância post-mortem que se lhe imputou durante as investigações. A data da sua chegada na comunidade é incerta, pois alguns depoimentos falam em 1818 e outros em 1819.

${ }^{27}$ Depoimento de Antonio Bezerra de Mello e outros. 17.11.1820. “Autos de Devassa”. IJJ'245/ANRJ.
} 
pacífica e natural concorrência de vizinhos para um lugar de fé, num movimento que transbordava inteiramente a proposta original e que, entre outras coisas, outorgava determinados fundos monetários aos organizadores ${ }^{28}$. Dirigidos por Paixão, Silvestre, seus irmãos e cunhados "vierão fabricar outro mocambo grande junto á huma Pedra, que ficava em pouca distancia no principio da Serra, e para ali mudarão algumas imagens que tinhão". Dai à elaboração consciente do mito não se passou muito tempo: Silvestre propalou a informação de que uma das imagens era milagrosa e as centenas de homens e mulheres que acudiram para ver a Santa foram rapidamente convertidos em associados da Irmandade do Senhor Bom Jesús ${ }^{29}$. Porém, nenhuma trangressão das normas morais ou religiosas foi detectada nesses princípios. Conforme a narrativa elaborada pelos testemunhas, o grupo, "com a crença e fanatismo que he vulgar nos rústicos", mantinha-se dentro dos limites do que a sociedade circundante considerava ser "a Religião do Paiz" ". A seleção dos participantes também parecia obedecer a critérios comportamentais que privilegiavam a ordem e a observância dos bons costumes: "recebião mulheres que usassem de tratamentos honestos e homens que fossem em graça" forte participação feminina, sobretudo de mulheres e parentes dos homens alistados. Curiosamente, atribuiu-se a elas uma função de "vigilância" da sexualidade e da moralidade no acampamento sem paralelo nessas épocas e nessas paragens. Dado que as reuniões de rezas aconteciam à noite, duas delas, companheiras de líderes

\footnotetext{
${ }^{28}$ Além de uma taxa para entrar na organização, os dirigentes cobravam pela participação nas rezas duas patacas por homem solteiro e quatro por casado. Não há informações sobre o destino dos fundos arrecadados. Depoimento de Estevão Fernandes. 06.11.1820. "Processo Summario e Interrogatorio". IJJ'245/ANRJ.

${ }^{29}$ Depoimento de Jozé Pedro Ferraz de Azevedo. Capitão do Esquadrão de Cavalaria. 08.11.1820. "Autos de Devassa". IJJ'245/ANRJ.

${ }^{30}$ Depoimento de Caetano Jozé Ferreira de Moraes. Soldado. 07.11.1820. "Autos de Devassa". IJJ'245/ANRJ. A "Religião do Paiz" do soldado transformava-se porém na "Superstição Religiosa, nascida da ignorancia d'aquella gente, que era toda miseravel" do mais letrado Cirurgão-Mor. Depoimento. 07.11.1820. Idem. IJJ' 245/ANRJ.

${ }^{31}$ Depoimento de Vicente Alves da Silva. Sargento. 11.11.1820. “Autos de Devassa”. IJJ'245/ANRJ.
} 
da comunidade, atuavam como "Procuradoras da honestidade das mulheres", com a função específica de cuidar "para se não juntarem com os homens"

O poder elaborado pelo relato de Manuel Gomes com base na legitimidade advinda do contato direto que Silvestre teria tido com D. Sebastião era mantido através do monopólio de um saber específico que eles dois detinham: só eles sabiam o segredo e conheciam o sentido das cerimônias. A sustentação diária da legitimidade fundamentava-se na exclusiva capacidade desses dois dirigentes por comunicar-se com o Grande Encoberto, através de uma intermediária, uma imagem dita miraculosa, a Santa da Pedra ${ }^{33}$. A articulação do poder era assim toda ela feita em torno de um elementar sistema de conhecimento cifrado, ao qual somente tinham acesso aqueles que controlavam o grupo: conhecer o segredo, compreender o sentido, escrever a profecia, traduzir a revelação.

Dos outros componentes da lenda, dois interessam particularmente a este estudo: as motivações que levaram os participantes a juntar-se à comunidade, segundo os próprios depoimentos e respostas aos interrogatórios, e o sentido dos milagres que se esperavam do Grande Encoberto. Ambos, motivações e expectativas são, naturalmente, complementares. Esses ingredientes resultam chave para permitir estabelecer a ponte entre a representação místico-religiosa do imaginário dos devotos e os fins concretos próprios de camponeses expropriados, pois embora as razões que levaram muitos dos membros a se juntarem à comunidade possam estar formuladas na esfera do religioso, elas atentam sempre para uma melhora imediata das condições concretas de vida dos participantes. Assim, por exemplo, um deles, introduzido no

\footnotetext{
${ }^{32}$ Depoimentos de Feliciana Maria da Conceição, mulher de Estevão Fernandes, e de Francisca Maria de Santa Anna, casada com Antonio Pereira, compadre do Silvestre. 21.11.1820. "Interrogatorios feitos às Mulheres". IJJ'245/ANRJ. Todas as seis mulheres presas declararam nada saber sobre o movimento. Uma delas respondeu as perguntas dizendo apenas "que era muito besta", e a irmã de Silvestre, Manoela Maria, informou que "nem ás mulheres se explicava". No oficio que acompanhava os autos do interrogatório recomendava o General José Félix Pereira de Vasconcellos que as mulheres fossem soltas, pois "dos seus interrogatórios se induz ignorancia, e huma Rusticidade a mais exaltada”. Presidente da Comissão a Governador. Recife, 22.11.1820. IJJ 245.

${ }^{33}$ Depoimento de João Fco. da Silva. 09.11.1820. “Autos de Devassa”. IJJ'245/ANRJ.
} 
grupo pelo próprio Silvestre, disse ter sido convidado a "viver na Serra do Rodiador aonde junto com outros deffendessem a cauza da verdadeira Fé e Religião de Nosso Senhor JesusChristo, e de ElRey D. Sebastião", para depois “tomar Pernambuco" e posteriormente liberar Jerusalem ${ }^{34}$. Parece claro que, no contexto estabelecido em torno do episódio, "tomar Pernambuco" devia ser entendido pelos membros da comunidade como o ato de assumir um poder que permitisse acabar com as mazelas que os afligiam, e não como uma conspiração de natureza política, no sentido pleno do termo. O próprio fato do milagre tem também um sentido metafórico iniludível, quase inerente. Pouco antes do anunciado descobrimento de El-Rei, dezenas de homens e mulheres dirigiam-se à sede da comunidade, "por dizerem que a referida Pedra era Lugares Santos, e que huma Senhora que alli havia em hum Mocambo que tinhão erigido em Capella, fazia muitos milagres"

A mesma natureza da principal característica da comunidade do Rodeador, aquela que projetou o trágico facho de luz que levou ao seu extermínio, isto é, o fato de ser primordialmente um crescente agrupamento de desertores e evasores do recrutamento militar, explica a primeira motivação. Foge-se do alistamento e do próprio serviço militar, como se foge de uma condenação injusta e arbitrária. Mas a fuga converte quem a pratica em desertor, fora-da-lei, que só pode encontrar refúgio e segurança onde outros trangressores como ele - não necessariamente culpados do mesmo delito - são maioria. Assim, "as milícias e Tropas se acabarião logo que aparecesse El Rey Dom Sebastião"; "que as milícias se havião de acabar, e tudo havia [de] mudar-se" ${ }^{\text {"36 }}$. Mas o milagre precisava ser ajudado. Talvez aqui repouse a principal diferença entre os quadros do Rodeador e as bases. Enquanto estas últimas simplesmente assistiam às rezas aguardando o momento da revelação, os primeiros

\footnotetext{
${ }^{34}$ Depoimento de Jozé Fernandez. "Conselho de Investigação”. 28.10.1820. IJJ $245 . / A N R J$

${ }^{35}$ Depoimento do Cyrurgião-Mor. 07.11.1820. “Autos da Devassa”.IJJ'245/ANRJ.

${ }^{36}$ Capitão Manoel Bezerra de Mello. Depoimento prestado em 16.11.1820; Depoimento de Antonio Ferreira no Hospital do Recife. 22.11.1820. Ambos em "Processo Summario e Interrogatorio". IJJ $^{9} 245 / A N R J$.
} 
agiam para encaminhar o sentido do milagre que esperavam: o jornaleiro Antônio Ferreira, um dos cunhados de Manuel Gomes, ferido no combate, declarou "que aquella Sociedade era para sahirem a emmendarem o mundo ["tomar Pernambuco"], e corrigi-lo, que tudo estava muito caro, q. quem não tinha dinheiro não podia enterrar-se na Igreja" $"$. Se a fuga do recrutamento criava a expectativa do milagre que acabaria com as milícias, a expansão da pobreza entre os grupos de camponeses expropriados forjava o reflexo da comunhão, pois vindo D. Sebastião, "nesta occazião se dividirião os bens" ${ }^{, 38}$, nesse dia abençoado "todos havião de ser ricos"

\section{b. As bases sociais do milagre}

Dezesseis dos vinte e três participantes do movimento da Pedra do Rodeador que foram presos e interrogados declararam ser camponeses sem terra que "viviam das suas enxadas". Dos 23, a grande maioria declarou não saber nada sobre questões substantivas da comunidade, e afirmou ter entrado no grupo "apenas pelas rezas". Vários negaram inclusive ter tido conhecimento do que se passava, dizendo terem sido presos "por engano" ou justificando a sua presença no local por motivos alheios ao movimento ${ }^{40}$. Com exceção de um homem que afirmava ter 45 anos todos os outros estavam compreendidos numa faixa etária bastante significativa: entre $20 \mathrm{e}$ 35 anos. Isto é, eram certamente filhos de famílias de cultivadores pobres livres, nascidos durante o período mais agudo do processo de expropriação desse segmento do campesinato nordestino, especialmente a última década do século anterior. Assim,

\footnotetext{
${ }^{37}$ Depoimento de Antonio Ferreira no Hospital do Recife. 22.11.1820. "Processo Summario e Interrogatorio". IJJ'245/ANRJ.

${ }^{38}$ Capitão Manoel Bezerra de Mello. Depoimento prestado em 16.11.1820. "Processo Summario e Interrogatorio". IJJ'24//ANRJ.

${ }^{39}$ Depoimentos de Feliciana Maria da Conceição, mulher de Estevão Fernandes, e de Francisca Maria de Santa Anna, casada com Antonio Pereira, compadre do Silvestre. 21.11.1820. "Interrogatorios feitos às Mulheres". IJJ'245/ANRJ.

${ }^{40}$ José Severino, por exemplo, declarou que estava indo caçar e pescar pacificamente quando foi preso e incorporado ao grupo de rebeldes. José Francisco da Rocha declarou-se "preso por engano", pois tinha estado apenas uma vez no reduto dos devotos para cobrar uma dívida. João $F^{\mathrm{co}}$ Alves e Jozé Thimoteo da Fonseca, alfaiate, declararam nunca ter estado na Pedra. "Processo Summario". IJJ'245/ANRJ.
} 
tudo indica que estamos diante de membros da primeira geração de expropriados, numa vertente de diferenciação "horizontal": são agricultores pobres que perderam as condições de acesso à terra nos seus lugares de origem, que não se integraram (ainda?) ao sistema plantation/morador, e que preferiram migrar à procura de novas oportunidades. Deles, apenas quatro pareciam ser naturais da comarca do Bonito, tendo os outros migrado de regiões tão distantes quanto os Carris Velhos, e Crato do Bom Jardim, no sertão do Ceará. Com a exceção de um deles, proveniente da comarca do Unna, no sudeste da capitania, os restantes configuravam tipicamente uma migração intra-agreste, um movimento horizontal mais do que vertical, que indica grande mobilidade e uma enorme extensão de território coberta por essas migrações. Eram indivíduos que tinham nascido já nos lugares de destino do êxodo da população camponesa, e não mais nas áreas da mata cultivadas ao longo do século XVIII.

Presos no Rodeador. Trabalhadores de enxada ${ }^{41}$

$\begin{array}{lllll}\text { Nome } & \text { IDADE } & \text { Cor } & \text { Est.CIVIL } & \text { NatuRAL } \\ \text { Antônio Ferreira } & 45 & \text { Pardo } & \text { Casado } & \text { Rodeador } \\ \text { Antônio M. Rodrigues } & 20 & \text { Pardo } & \text { Casado } & \text { Goiana } \\ \text { Antônio Pereira } & 36 & \text { Pardo } & \text { Casado } & \text { Cariris V. } \\ \text { Bernardo M. da Silva } & 26 & \text { Mulato } & \text { Casado } & \text { Cariri } \\ \text { Fco. Xavier das Chagas } & 30 & \text { Branco } & \text { Casado } & \text { S.do Macaco } \\ \text { João Fco. Alves } & 32 & \text { Pardo } & \text { Casado } & \text { Crato } \\ \text { José Fco. da Rocha } & 35 & \text { Branco } & \text { Casado } & \text { Limoeiro } \\ \text { José Severino } & 28 & \text { Pardo } & \text { Solteiro } & \text { S. Antão } \\ \text { José Soares da Cruz } & 25 & \text { Pardo } & \text { Casado } & \text { Limoeiro } \\ \text { Luís Antônio César } & 30 & \text { Pardo } & \text { Casado } & \text { Unna } \\ \text { Manoel J. do Nacimento } & 30 & \text { Pardo } & \text { Casado } & \text { N.S.Gloria } \\ \text { Manoel Pereira Gomes } & 26 & \text { Pardo } & \text { Casado } & \text { Bonito } \\ \text { Manoel Pereira Pinto } & 26 & \text { Pardo } & \text { Casado } & \text { S/l } \\ \text { Manuel Telles } & 36 & \text { Pardo } & \text { Casado } & \text { Bonito } \\ \text { Pedro Francisco } & 30 & \text { Pardo } & \text { Casado } & \text { Garanhus (?) } \\ \text { Serafim José de Oliveira } & 25 & \text { Pardo } & \text { Casado } & \text { Bonito }\end{array}$

\footnotetext{
${ }^{41}$ Dos sete presos restantes dois eram proprietários de terras relativamente abastados, pois ocupavam postos de capitães de milicias ou ordenanças. Ambos eram brancos, homens de meia idade (55 e 60 anos) e naturais da própria comarca do Bonito. Outro, também natural da comarca, declarava viver de "plantar cannas" numa engenhoca, mas o entrevistador não se interessou por pesquisar as
} 
Com a ressalva dos dois oficiais, a totalidade dos moradores da comunidade do Rodeador eram, como convém a camponeses sem terra, extremamente pobres. No entorno de proteção concedido pela lenda, pobreza e falta de terra tinham sido motivações centrais para a amálgama do grupo. O próprio Ouvidor do Recife percebia o sentido do milagre, a sua natureza alegórica e explicava assim o grande afluxo de pobres livres em direção à serra: "Achando excelente agoa, um terreno fértil para manter suas famílias, e uma sociedade ao parecer virtuosa, que lhes proporcionava a segurança, julgarião sem duvida ter achado uma terra semelhante á da Promissão" ${ }^{42}$.

Tratava-se, então, de uma região de fronteira, de grande fertilidade, ainda não inteiramente dominada pela lógica das plantations, e para onde camponeses como Luís Antônio César, expulsos das novas áreas de exclusão, iam "assistir ali procurar trabalhar para sustentar a sua familia" ${ }^{43}$. No Rodeador se formara então uma típica comunidade de cultivadores livres, dedicada aos plantios que caracterizavam a agricultura desses segmentos, sobretudo roçados de mandioca e de feijão ${ }^{44}$, socialmente organizada de acordo com preceitos partilhados pela sociedade em geral e classicamente isolada. A rotina da comunidade foi assim caracterizada por um dos interrogados: "vivião do seu trabalho, pois tinhão rossas, e sementeiras e davão ordem a

condições desse plantio. Três eram praticantes de oficios: um alfaiate, originário da vizinha comarca de Garanhus, e dois ferreiros/serralheiros, vindos de Tracunhaem e de Capibaribe, Estevão Fernandes e o seu filho José Fernandes Coutinho, membros estratégicos do grupo central, pois eram os supostos encarregados da manutenção das armas. A lista se encerrava com um jovem cego que declarou viver de esmolas e ter ido à pedra em busca de um milagre particular que lhe devolvesse a visão. "Processo summario e interrogatorio". IJJ'245/ANRJ.

${ }^{42}$ Ouvidor Geral da Comarca do Recife a Governador da Provincia. Recife, 04.12.1820. IJJ $245 /$ ANRJ.

${ }^{43}$ Depoimento de Luiz Antonio Cezar, ferido, no Hospital do Recife. 22.11.1820. "Processo Summario e Interrogatorio". IJJ'245/ANRJ.

${ }^{44}$ Depoimento de Caetano Jozé Ferreira de Moraes. 07.11.1820; “Autos de Devassa”. IJJ'245/ANRJ. É instigante a ausência de menções a culturas de algodão, que nas décadas anteriores tinha sido um dos produtos mais favorecidos nas comunidades de cultivadores livres de Pernambuco. Uma possível explicação, além, naturalmente, de prováveis inexactidões da fontes, pode estar no tempo de vida da comunidade, isto é, no tempo necessário para reorganizar a produção após o movimento desagregador manifestado nas migrações. 
sua vida, sem haver queixa de furto, ou crime por elles praticados", 45 "[...] sendo tudo huma gente dispresivel, quasi todos cabras, e mulatos, que vivião do trabalho das suas máos [...]" "Clássicas eram também as formas que a comunidade empregara para garantir o seu acesso à terra, embora exista mais de uma versão em torno desse assunto. Uma delas, a mais próxima dos acontecimentos, pois, foi estabelecida no interrogatório das testemunhas, mas também altamente interessada, já que partia do pai do suposto proprietário das terras, indica que a familia extensa de Silvestre - "huns Pardos" - ter-se-ia fixado originalmente em terras aforadas de um João Francisco da Silva. Segundo esse relato, com o correr dos anos, e provavelmente fortalecidos com o aumento da popularidade das rezas e o crescente poder que os seguidores da Pedra lhes conferiam, os líderes do movimento decidiram suspender o pagamento. Desconheceram a carta de sesmaria que o pai do João Francisco jurava existir, e passaram a reclamar o seu direito de permanecer em terras que eles diziam ser apenas realengas: "e querendo o mesmo seu filho haver os ditos fôros, se-temeo delles, por ver, que fazião hum partido [...] e só lhe consta, que elles dizião, que Sua Magestade no era nada, em chegando El Rey Dom Sebastião" ${ }^{47}$. A importância da questão fundiária e do desafio da contralegitimidade para a construção da causa que se haveria de formar à comunidade camponesa está resumida no traço firme do lápis do insquisidor que sublinhou as frases indicativas de delito. Delito comum e delito político, terra e estruturas de poder intimamente vinculadas, complementos uma da outra. Seria interessante estabelecer se a suspensão do pagamento do foro tinha coincidido, como tudo indica, com o arrefecimento dos movimentos de repúdio ao domínio português no Brasil. A segunda versão fortalece esta hipótese, e aumenta a com-

\footnotetext{
${ }^{45}$ Depoimento de Alejandre Magno dos Reis. 07.11.1820. “Autos de Devassa”. IJJ'245/ANRJ.

${ }^{46}$ Depoimento de Manoel Gonçalves da Silva, Tenente Quartel-Mestre do Esquadrão de Cavalaria. 08.11.1820. "Autos da Devassa”. IJJ'245/ANRJ.

${ }^{47}$ Depoimento de Manoel Pereira da Silva. 09.11.1820. "Autos de Devassa”. IJJ'245/ANRJ. Sublinhado a lápis no original. José Fernandes, o armeiro do grupo, identificou João Francisco como Sargento de Ordenanças e membro assiduo e influente nas reuniões da comunidade, à qual teria oferecido "todos os seus bens". Depoimento de Jose Fernandes Coutinho. "Conselho de Investigação". 28.10.1820. IJJ'245/ANRJ.
} 
plexidade do Rodeador, pois identifica os membros da comunidade como posseiros e invasores: "He verdade que muitos individuos isolados, e outros com famílias, se havião apoderado daquelle sitio, sem ser por meios legaes, e se furtavão por isso de se submeterem as authoridades locaes". Mas não eram simples agricultores pobres, e sim

“[...] uma reunião de homens suspeitos, sendo alguns desertores, e outros que havião tomado parte na revolução de 1817 , que ali se refugiarão, que no dito lugar se havia constituido uma povoação independente das authoridades locaes, que tinhão officinas, armamentos, e munições, que uzavão um Patuá pelo qual se entendião [...] e que havião todas as apariencias que essa munição, q. diariam ${ }^{\text {te }}$ se augmentava, era um foco de rebelião [...]" (Narrativa c1860a:1) ${ }^{48}$.

Diversas informações constantes dos autos indicam que, de fato, o início do povoamento da serra do Rodeador pelo grupo de Silvestre iniciara-se por volta de 1817. Outro dos interrogados pelo Conselho de Investigação, Antônio Pereira, cunhado do Silvestre, declarou ter recebido a primeira proposta para se integrar ao grupo "haverá perto de trez annos", e ter encontrado quando chegou, ainda em 1817, já “de huma duzia ate vinte homens". O suposto emprego de um "patuá" como linguagem cifrada acompanhava naturalmente o terror republicano que grassava entre as autoridades portuguesas em Pernambuco desde os anos da Revolução francesa ${ }^{49}$.

\section{b. 0 jogo das instâncias culturais}

Outra imagem fortemente definida por diversos depoimentos se contrói na base da combinação de atributos raciais, miséria e formas culturais resultantes. As menções à pobreza extrema da comunidade do Rodeador estão quase sempre acompanhadas de comentários sobre aspectos raciais, que funcionam como explicações da

\footnotetext{
${ }^{48} \mathrm{O}$ texto, escrito, como já foi dito, na década de 1860, retroage as disposições da Lei de Terras de 1850 para 1820, quando a posse "mansa" era evidentemente uma forma generalizada de apropriação da terra.

${ }^{49}$ Depoimento de Antonio Pereira. 28.10.1820. "Conselho de Investigação”. IJJ'245/ANRJ. "Patuá", como se sabe, é um denominador genérico para diversos dialetos franceses.
} 
miséria, e que por sua vez parecem determinar na representação dos entrevistados uma cultura específica. A referência ao fato de serem a grande maioria dos habitantes do Rodeador "cabras" e "mulatos" transita facilmente pela condição de vida e termina por se traduzir em "ignorância": "aquelle ajuntamento era quase todo de molatos, e cabras, gente miseravel, e ignorante" ${ }^{, 50}$. É claro que a constância dessas referências à "ignorância" dos cultivadores pobres reunidos em torno da Pedra do Rodeador fala mais sobre os depoentes do que sobre a cultura dos pobres e livres da época, pois precisa ser formulada assim: "ignorância com relação a quê?". "Ignorância" aparece, então, como uma categoria agregada à pobreza, e ambas, combinadas com a caracterização racial mestiça, convergem para construir a imagem do camponês na sociedade escravista oitocentista. Quanto mais essa sociedade se apropria de e distribui entre os membros das suas elites estruturas e instrumentos culturais baseados na linguagem escrita, mas nitidamente "ignorante", e desqualificada, será a cultura dos grupos de cultivadores pobres. Desqualificada ao ponto de que por trás da proteção paternalista dos depoentes entrevistados pelo Ouvidor esconde-se, de fato, a confirmação da marginalidade como um destino pré-determinado, um universo delimitado pela exclusão que a cultura letrada demarca: "sendo toda essa gente huns miseraveis, pardos e cabras, no julga que a sua associação podesse ser perigosa" ; " "não julga elle testemunha, atenta a sua estupidez, e pobreza, que os mesmos podessem ter outro fim maior" ". A "ignorância" explica o milagre, ou melhor, a "superstição", e sob a sua base se fundamenta, como vimos anteriormente, o domínio do grupo dirigente sobre a comunidade de fiéis: tanto Manoel quanto Silvestre são alfabetizados - o primeiro mais do que o segundo - e sob esse

\footnotetext{
${ }^{50}$ Depoimento de Caetano Jozé Ferreira de Moraes. 07.11.1820; "sendo tudo huma gente dispresivel, quasi todos cabras, e mulatos": Depoimento de Manoel Gonçalves da Silva, Tenente Quartel-Mestre do Esquadrão de Cavalaria. 08.11.1820. "Autos da Devassa". IJJ'245/ANRJ.

${ }^{51}$ Depoimento de Jozé Ferraz de Azevedo, Capitão do Esquadrão de Cavalaria. 08.11.1820. “Autos de Devassa".IJJ9245/ANRJ. Depoimento de Jozé Manoel Villaverde. 09.11.1820. Idem.

${ }^{52}$ Depoimento de Jozé Manoel Villaverde. 09.11.1820. “Autos de Devassa”. IJJ'245/ANRJ.
} 
atributo se estrutura o sistema de poder. Típicos mediadores culturais, elos entre a tradição oral dos cultivadores pobres e a emergente cultura grafocêntrica que se espalhava a partir dos centros de poder econômico da sociedade rural ${ }^{53}$. Sobre essa "ignorância" se fundamenta, por último, a versão nascida das conclusões dos inquéritos e difundida nas narrativas do último quarto do século que reduz o movimento, na sua essência, a uma "esperteza" dos alfabetizados e os seus cúmplices sobre os incultos camponeses que se juntaram à comunidade ${ }^{54}$. Apenas a veracidade do milagre é negada por todos os autores, embora o coronel Chagas, pioneiro das reflexões sobre o imaginário, num verdadeiro achado afirmasse que Silvestre "ahi estava reunindo gente para que em tempo opportuno ouvisse a huma Santa que ia falar para mostrar o bom caminho por onde o povo devia seguir". Isso preparava o milagre, pois a imagem era uma dupla alegoria: era "a Santa Liberdade, era a Independencia do Brasil" (Chagas1890: 82).

As informações transmitidas pelas fontes não são suficientes para sequer rascunhar uma visão geral do universo cultural dos cultivadores pobres livres, pois elas claramente enquadram e reformulam em linguagem compreensível para as autoridades policiais depoimentos que devem ter privado pela simplicidade das respostas, característica tanto da relação dos cultivadores pobres e livres com pessoas estranhas

\footnotetext{
${ }^{53} \mathrm{O}$ grau de instrução de Silvestre é incerto. José Fernandes, por exemplo, declarou que Silvestre "ainda que não sabia ler, e escrever, ditava, e outro escrevia que se chamava Manuel da Paixão". Depoimento de José Fernandes Coutinho. "Conselho de Investigação". 28.10.1820. IJJ"245/ANRJ. Já o Ouvidor do Recife chama Silvestre, de "homem rustico e ignorante, mas pressumido de scientifico, porque sabia ler, e referir a historia do Sebastianismo". Ouvidor Geral da Comarca do Recife a Governador da Provincia. Recife, 04.12.1820. IJJ'5245/ANRJ. J.A. Costa contradiz esses documentos e chama Silvestre de "um desses sertanejos ou matutos sem a minima instrucção, porém muito astuto" (Costa 1880: 341).

${ }^{54}$ Ouvidor Geral da Comarca do Recife a Governador da Capitania. Recife, 04.12.1820. IJJ $245 /$ ANRJ; Costa 1962, v. VIII: 91; Amaral 1884a: 157; Costa 1880: 342-343; Varnhagen 1975, t. 5:179. ${ }^{55} \mathrm{O}$ autor não indica nenhuma fonte empregada para redigir o texto, que aliás não foge ao teor das outras narrativas, embora carregue as tintas contra os "proprietários portugueses" que teriam sido os primeiros a soar o alerta contra a presença do Silvestre. A outra originalidade do texto é fazer do lider do Rodeador um personagem tão "misterioso" como o próprio D. Sebastião.
} 
à comunidade, quanto, sobretudo, das circunstâncias prevalecentes de extraordinária tensão e violência, a montante e a jusante, nos interrogatórios. Isso, evidentemente, sem falar do direcionamento absolutamente proposital dos inquéritos, atrás de uma narrativa que se acoplasse às teses do poder repressor. $\mathrm{O}$ resultado são respostas achatadas, repetitivas, confirmatórias as mais das vezes. Como já foi dito, o conjunto documental pode servir antes para fazer um desenho da mentalidade das instâncias repressoras do que para penetrar no imaginário dos reprimidos. Mas algumas questões podem ser ao menos apontadas.

Evidentemente, a reprodução da tradição do sebastianismo na comunidade da Pedra do Rodeador, e a função central atribuída no sistema ritual a artefatos culturais externos à comunidade camponesa, coloca-nos imediatamente diante de graus de complexidade intercultural acima do padrão normal que se poderia esperar numa comunidade de cultivadores pobres livres do interior do Nordeste brasileiro nas primeiras décadas do século $\mathrm{XIX}^{56}$. Porém, mais importante é a especial atribuição transitiva que as manifestações da nova cultura recebem no sistema de coesão social da comunidade. Como em outras situações históricas, Silvestre e Paixão transitam entre a cultura oral predominante no grupo de devotos e a cultura escrita de que se alimentam as diversas reformulações da lenda. Eles fazem com que o ato da leitura textual se incorpore mansamente, e de maneira absolutamente central para a organização do rito, à cultura ancestral dos membros da comunidade, como um novo mecanismo de hierarquia que, externo à cultura do grupo, se introduz e diferencia, criando novas relações de poder. A leitura usa-se para reafirmar

\footnotetext{
${ }^{56}$ Ao que parece, as lendas sobre a volta de D. Sebastião estavam tendo grande circulação por esses anos em Portugal, por causa da polémica suscitada com a publicação dos folhetos Os Sebastianistas, do padre José Agostinho de Macedo (Lisboa, Na Officina de Antonio Rodrigues Galhardo, 1808), que respondia a um surto de sebastianismo provocado pela invasão francesa (Azevedo 1947: 93). Em tempo, Azevedo, com retórica tipicamente ariana, despreza como simples embuste as "imitações" brasileiras de lendas sebastianistas: "Nada tinham tais factos com a lenda do patriotismo português. A tradição, constante no povo, deformara-se ao contacto da mestiçagem, mal integrada na civilização. Amalgamou-se com reminiscências de contos de fadas, e o resto foi o recordar inconsciente de ritos bárbaros dos antepassados, nos tempos em que ao sangue índio e africano se não mesclara ainda o do europeu" (Idem: 100).
} 
e consolidar a tradição oral: as cerimónias estão centradas na transmissão escrita dos oráculos revelados (verbalmente?) ao propheta pelo Grande Encoberto.

De alguma maneira, assim, a experimentação das novas estruturas de controle social, fundamentadas na expansão e domínio de um certo conjunto de instrumentos culturais que se geram no seio das camadas dominantes da sociedade - aqui representados pela palavra escrita -, faz com que elas se antecipem como elementos absorvidos na cultura da comunidade, através das suas funções transitivas, à sua chegada como elementos tipicamente aliados aos inimigos históricos das comunidades de cultivadores libres y pobres de Pernambuco. Dessa maneira, cria-se uma forma especificamente camponesa de ler e interpretar materiais culturais produzidos fora do âmbito cultural das comunidades, que estará crescentemente em evidência a partir desses anos, sobretudo nas peculiares interpretações que diversos grupos de cultivadores livres farão de textos legais e normativos produzidos pelo novo Estado nacional, e orientados na sua direção ao longo do tortuoso processo de abolição da escravidão no Nordeste do Brasil (Palacios 1996).

Essa forma particular de ler e interpretar, infinitamente mais fácil de identificar do que de descrever, amplia os horizontes dos sistemas cognoscitivos vigentes nas camadas camponesas e constrói, de fato, novas pontes de comunicação - e, mais freqüentemente, novas avenidas de conflito - com a cultura oficial e os seus portadores. O conflito instalase então também na dimensão do significado. Impregnada de elementos construídos a partir da representação da escravidão no imaginário dos pobres livres, essa leitura peculiar precederá a revolta contra o Registro de Nascimentos e Obitos em 1852, o Quebra-Kilos em 1875 e inclusive Canudos em 1892 - movimentos com frequência reinterpretados, do lado de cá, como meramente antimodernizantes e reacionários.

Se levarmos em consideração que o processo de abolição da escravidão corre paralelo a um outro movimento de edificação de uma nova estrutura de relações hegemônicas para articular os novos sistemas de controle social do trabalho que se preparam no intuito de substituir a violência nua do cativeiro, e que essas novas estruturas reservam um lugar central para os instrumentos culturais e ideológicos de subordinação, Silvestre e Manoel Paixão eram certamente personagens do novo século. 
Mas eram também, junto com os seus seguidores, representantes legítimos do velho sistema e das suas antigas lealdades ao regime agonizante, lealdades que tão nitidamente pareciam ter agido sobre os cultivadores pobres livres em 1817, "na ultima crize d'esta Capitania, em que deixando voluntariamente suas habitações, descerão armados com o Estandarte Real na mão á deffender a causa da Fidelidade" ${ }^{, 57}$.

Uma palavra sobre a Igreja. É notável a sua quase total ausência no episódio do Rodeador. Um padre, que assistia a comunidade nos primeiros anos, fugiu aparentemente assustado com as propostas de Manuel Gomes. Como as devoções eram levadas a sério e tinham funções especiais na organização comunitária - "os ditos homens são muito devotos porque exigem dos que se querem alistar se confessem" - uma filha de Gomes passou a partir desse momento a responder pelas confissões populares, distribuindo penitências e absolvições, e previsões de riqueza e abundância geral aos que habitassem na "Pedra a que elles chamão Cidade do Paraizo Terrenal" ${ }^{58}$. Em anos posteriores, sobretudo a partir de 1840, nenhum movimento dessa natureza ficaria longe da intervenção miraculosa e espantosamente eficiente dos capuchinhos italianos (Palacios 1996: 131-133).

\section{Epílogo}

No dia 24 de novembro de 1820, há um mês do massacre da Pedra, o Conselho Militar de Investigação nomeado pelo Governador Luis do Rêgo deu o seguinte parecer final sobre o movimento:

\footnotetext{
${ }^{57}$ Ouvidor Geral da Comarca do Recife a Governador da Capitania. Recife, 04.12.1820. IJJ ${ }^{9} 245 /$ ANRJ. Segundo o Ouvidor, que talvez pensava no contexto da sua própria frase, o ataque ordenado pelo Governador "occasionou a catastrofe que terá de lamentar-se por muito tempo".

${ }^{58} \mathrm{Cm}^{\text {te }}$ da $2^{\text {a }}$ Brigada a Governador. Limoeiro, 20.10.1820; Depoimento de José Fernandes. "Conselho de Investigação”. 28.10.1820. IJJ $^{9} 245 / A N R J . ~ O$ primeiro reproduz informações transmitidas pelo pombeiro. Outras comunicações comprometem também dois padres, "Lza e Bastos", que conseguiram fugir. Marechal de Campo a Governador. Bonito, 29.10.1820. IJJ'245/ANRJ.
} 
"[...] a Sociedade, ajuntamento ou associação da Serra do Rodeador deve ser considerado, como feita para Conselho, e confederação contra ElRey, e contra o Estado, e que os Seus Autores, e Cabeças, ou Chefes da mesma associação; e bem assim todos aqueles na mesma empregados [...] se devem considerar Reos deste nefando attentado [...] a penetração do mais rustico, e Salvagem camponez, que de nada lhe pode servir de quartada, ou deffeza o dizer que ignorava para que era similhante ensaio e preparo [militar],"59.

O veredicto estava sustentado numa leitura inteiramente política do movimento, sem atentar para nenhuma das suas atenuantes. Eliminando, ou não percebendo, com típica astúcia militar, o centro real do processo, o encarregado do inquérito, João Felix Pereira de Campos, Chefe de Divisão, não teve dificuldade para desviar o foco da atenção afim de preencher os medos do Governador, certamente inflamados com as notícias da Revolução do Porto e do impasse entre El Rei e as Cortes, que chegavam a Pernambuco por esses dias ${ }^{60}$. Assim, Campos apontou para a periculosidade do movimento do Rodeador pela velocidade de bola de neve com que crescia em termos numéricos, e pelo que lhe parecia ser uma maquiavélica adequação de meios e fins, religião e simplicidade, tudo isso emoldurado pela desestruturação reinante nos esquemas de organização social, política e econômica da década de 1820, a desmontagem de uma ordem secular, particularmente aflitiva, por outro lado, para mentalidade da caserna. Isso, é claro, sem levar em consideração que grande parte desse sentimento coletivo de desamparo e desespero entre as comunidades do interior misturava, na sua própria e exclusiva fórmula histórica, a ameaça do caos presente na destruição do regime colonial com a completa desestabilização da sociedade camponesa do Nordeste

\footnotetext{
59 "Juizo ou opinião do Conselho" em "Processo summario e interrogatorio". 24.11.1820. IJJ $245 /$ ANRJ.

${ }^{60}$ Sobre o entorno macro-político dos acontecimentos da Serra do Rodeador existe uma abundante bibliografia, quase toda ela de cunho eminentemente político. Entre as visões de conjunto mais competentes, veja-se Silva (1986a: 397-407); Bethell (1989a: 25 e ss.). Sobre o contexto político pernambucano existem poucos estudos. No entanto, Mota (1972a), continua sendo, embora muito suscinto, o mais valioso.
} 
Oriental nas décadas imediatamente precedentes. Campos, alheio a isso, tocava no entanto em pontos chave:

\begin{abstract}
"e os meios que se empregavão para as suas aquizições erão acreditaveis na classe de gente que procuravão, e admitião, e que pela sua ignorancia, rusticidade e superstição para que todos ou a maior parte dos homens do Matto tem huma tendencia sem limite, e por ella de ordinario dirigem todas as suas acções [...] até mesmo atendendo este Conselho á delicadeza das circunstancias da desgraçada Epoca em que vivemos, em que a maior parte dos homens parece terem dellirado e não saberem o que elles mesmos querem, e cuja molestia tanto se tem propagado infelizmente, que até tem contagiado os mais rusticos, e inertes [...]".
\end{abstract}

As principais acusações concretas contra a comunidade do Rodeador, a saber, que realizavam exercícios militares para atacar o Estado, e que, armados, tinham resistido à investida do exército, foram todas rebatidas pelo Ouvidor. Os "exercícios", já ridicularizados por diversas testemunhas e pateticamente descritos pelos próprios presos, limitavam-se a marchas de poucos metros, meia-voltas e ocasionais tiros de espingarda, geralmente para avisar do amanhecer e acordar os fiéis. Dificilmente poderiam ser levados a sério como partes de um plano de "preparo militar", conforme queria o encarregado do Conselho de Investigação. A questão de estarem todos armados diluía-se no ambiente e nos costumes de violência generalizada como normas de conduta amplamente aceitas e conhecidas. Todo mundo no campo andava armado: "Ninguem ignora que as espingardas, e espadas são tão vulgares na gente do Matto, como os floretes, e espadinhas na Corte”. Quanto à resistência ao ataque, as circunstâncias, a própria brutalidade e a completa incompetência dos oficiais de mando, atenuavam qualquer culpa ${ }^{62}$.

O Governador, no entanto, fiel às suas inimizades, manteve a versão militar no momento de encaminhar o processo definitivo, composto pelos autos do Conselho de Investigação e pela Devassa do Ouvidor, ao Ministério do Reino, e justificou o

${ }^{61}$ Presidente do Conselho de Investigação a Governador. Recife, 24.11.1820. IJJ'245/ANRJ.

${ }^{62}$ Ouvidor Geral da Comarca do Recife a Governador da Capitania. Recife, 04.12.1820. IJJ'245/ANRJ. 
emprego de numerosas tropas de linha no cerco à Pedra pela "facilidade que tem a gente dos matos em mudar de habitação mesmo para grandes distancias". De fato, como já tinha dito o Ouvidor, no começo do século XIX, da mesma maneira como ficaria patente 30 anos depois, durante a revolta contra o Registro de Nascimentos e Obitos, a liberdade "indenizava" os camponeses da sua pobreza ${ }^{63}$. O veredicto real, embora qualificado, e lamentando os excessos praticados pela tropa, pendeu também claramente para a defesa da ação de Luís do Rego, determinando a prisão e desterro para Angola de Silvestre José dos Santos, cinco anos de cadeia para os "instrutores" militares e armeiros da comunidade do Rodeador, e recrutamento compulsório, para servirem fora da Província, dos homens restantes. Depois, o perpétuo silêncio ${ }^{64}$.

Silvestre nunca foi encontrado, nem muito menos preso. Integrou-se à mitologia popular e, embora embusteiro, terminou fazendo parte da lenda que tinha construido: pelos menos dois autores afirmam que ele foi visto em 1821 entrando com os patriotas em Goiana, lutando pela independência do Brasil (Chagas 1890: 82; Costa 1962, v. VIII: 98). Certamente montado num nervoso e rampante cavalo branco.

\section{Arquivos consultados}

Archivo Nacional (RJ)

Archivo do IHGB

Arquivo Público Estadual de Pernambuco

Seções de Obras Raras e Manuscritos da Biblioteca Nacional do Rio de Janeiro.

\section{Fontes impressas e bibliografia referida ao Reino Encantado da Pedra do Rodeador.}

ABREU E LIMA, José Ignacio de. "Combate do Rodeador ou da Pedra (1820)"[c.1860]. RIAHGP, v. X, n.57 (março 1903), pp.251-257.

\footnotetext{
${ }^{63}$ Governador a Ministro do Reino. Recife, 12.12.1820. IJJ'9245/ANRJ.

${ }^{64}$ Ministro do Imperio a Governador. Paço, 12.01.1821. IJJ ${ }^{9} 245 / A N R J$.
} 
ALBUQUERQUE, Manoel Caetano de Almeida e."O Horroroso Massacre do Bonito", em Amaral, Escavações, pp.165-168. [c.1884].

AMARAL, F.P. do. Escavações, fatos da história de Pernambuco. Pernambuco, Typographia do Jornal do Recife, 1884.

“A Santa da Pedra”, em Escavações, pp. 154-164. 1884a

AZEVEDO, João Lúcio d'. A evolução do sebastianismo. Lisboa, A.M. Teixeira, 1947.

BARRETO, Luís do Rego. “Ordem dada pelo General [...], Governador da Capitania de Pernambuco, sobre o uso de armas na dita Capitania”. 01.12.1820.

CHAGAS, Francisco Benicio das, Cel. "História dos acontecimentos da Pedra do Rodeador”. RIAHGP, v.VI, n.37 (abril, 1890), pp.79-82.

Correio Braziliense ou Armazem Literario. vols. XXV e XXVI. Londres, R. Greenlaw, 1820-1821.

COSTA, F.A. Pereira da. "Folk-lore Pernambucano". RIHGB, n. 70 (2), 1907. pp.5-624.

Anais Pernambucanos. v.VIII: 1818-1823. Recife, Arquivo Público Estadual, $3^{\text {a }}$ ed., 1962.

COSTA, J. Augusto da. "Expedição do Rodeador", em Revista Brazileira. Primeiro anno, Tomo IV. Rio de Janeiro, N. Midosi Editor, Junho de 1880. pp.340-352.

Gazeta do Rio de Janeiro. Sábado 25 de novembro de 1820.

GAMA, Jozé Bernardo Fernandes. Memórias Históricas da Província de Pernambuco. Pernambuco, Na Typographia de M.F. de Faria, 1844.

HONORATO, Manoel da Costa. Dicionário Topográfico, Estatístico e Histórico da Província de Pernambuco. $2^{\mathrm{a}}$ ed. Recife, Secretaria de Educação e Cultura, 1976.

Levantamento Estatistico da População de Pernambuco, 1822. Biblioteca Nacional do Rio de Janeiro, Seção de Manunscritos.

"Luís do Rego Barreto, $1^{\circ}$ Visconde de Geraz do Lima". Boletim do Arquivo Histórico Militar, $9^{\circ}$ volume (1939). Vila Nova de Famalição, 1939. pp.2-4.

MAGALHIS, Rodrigo da Fonseca. Memoria Justificativa sobre a Conducta do Marechal de Campo Luiz do Rego Barreto durante o tempo em que foi Governador de Pernambuco, e Presidente da Junta Constitucional do Governo da mesma Província, offerecida á Nação Portuguesa. Lisboa, Typographia de Desiderio Marques Leão, 1822. 150p.

"Municipio do Bonito. Descrição do municipio do Bonito no ano de 1881". RIAHGP, v. VI, n.37 (abril 1890), pp.71-79. 
Narrativa referente a um ataque contra Bonito. Recife, s/e., c.1860, 4fls.

Narrativa dos acontecimentos referentes ao Governo do General Luiz do Rego e á reforma da tropa efetuada [...]. Recife, s/e, c.1860a, 4fls.

QUEIROZ, Maria Isaura Pereira de, O Messianismo no Brasil e no Mundo. São Paulo, Edusp, 1965.

RIBEIRO, René. “O episódio da Pedra do Rodeador (1817-1820): um movimento milenar e sebastianista". Revista de Antropologia, vol.8, n.2, dezembro de 1960.

SILVA, José Leonardo da (atribuido a). O Feitiço voltado contra a Feiticeiro [sic] ou $O$ Autor do Folheto intitulado os Sebastianistas, convencido de máo christão, máo vasallo, máo cidadão e o maior de todos os Tolos, Besta-muar, \&c, \&c, \&c. Londres, impresso por W.Lewis, Paternoster-row, 1810.

VARNHAGEN, Francisco Adolpho. História Geral do Brasil antes da sua separação e independência de Portugal. Rev. e notas de Rodolfo Garcia. São Paulo, Edições Melhoramentos, $8^{\text {a }}$ ed., 1975. t.5.

\section{Bibliografia de apoio}

BACZKO, Bronislaw. Los imaginarios sociales. Memorias y esperanzas colectivas. Buenos Aires, Ediciones Nueva Visión, 1991.

BETHELL, Leslie. Brazil. Empire and Republic, 1822-1930. Cambridge, Cambridge University Press, 1989.

"The Independence of Brazil", em Bethell, (ed.), Brazil. Empire and Republic, 1989a.

MOTA, Carlos Guilherme. 1822. Dimensões. São Paulo, Perspectiva, 1972

"O Processo de Independência no Nordeste", em Mota, 1822. Dimensões. 1972a.

PALACIOS, Guillermo. "Campesinato e escravidão: uma proposta de periodização para a história dos cultivadores pobres livres do Nordeste Oriental do Brasil, 1700-1875". Dados. Revista de Ciências Sociais. vol. 30, n.3, 1987.

"Imaginário social e formação do mercado de trabalho: o caso do nordeste açucareiro do Brasil durante o século XIX". Revista Brasileira de Ciências Sociais, ${ }^{\circ}$ 31, Junho de 1996.

Cultivdores libres, Estado y crisis de la esclavitud en Brasil en la época de la Revolución industrial. México, Fondo de Cultura Económica/El Colegio de México, 1998. 
SILVA, Maria Beatriz Nizza da (coord.). O Império Luso-Brasileiro, 1750-1822. Lisboa, Editorial Estampa, 1986.

"Da revolução de 1820 à independência brasileira", em Silva (Coord.), $O$ Império Luso-Brasileiro, 1986a. 